\title{
A new X linked mental retardation (XLMR) syndrome with short stature, small testes, muscle wasting, and tremor localises to Xq24-q25
}

\author{
David A Cabezas, Rachel Slaugh, Fatima Abidi, J Fernando Arena, Roger E Stevenson, \\ Charles E Schwartz, Herbert A Lubs
}

sixth affected male (III.14), who declined to participate and is not included in the haplotype pedigree. Blood was collected for DNA studies from 15 family members after informed consent was obtained.

\section{DNA STUDIES}

Genomic DNA was isolated from peripheral blood of members of family K8135 using a high salt precipitation method. ${ }^{3}$ Specific dinucleotide or trinucleotide polymorphisms were generated as given in Nelson et al ${ }^{4}$ or Dib et al. ${ }^{5}$ Forward primers for the PCR primer pairs were synthesised and labelled with fluorescein amitide (FluorePrime, Pharmacia) on a Beckman 1000 DNA synthesiser and desalted through Sephadex G-25 (NAP-10 columns, Pharmacia). The polymorphisms were detected using an automated Laser Fluorescent Sequencer (ALF, Pharmacia) in conjunction with Fragment Manager (Pharmacia) and the software package, Automated Linkage Preprocessor (ALP). ${ }^{6}$ CEPH person No 134702 was included in all microsatellite analyses as a means of accurately assigning the alleles at a particular locus.

Keywords: X linked mental retardation; Xq24-q25; syndrome

In the two year interval between the "XLMR Gene Updates" of $1996^{1}$ and $1998{ }^{2}$ the total number of known syndromes increased from 105 to 120 and the reported families with nonspecific XLMR (MRX) increased from 42 to 60. During this time the cloning or molecular characterisation of these disorders has resulted in the "lumping" of disorders found to be allelic, so that the overall increase in the number of syndromes represents the net result of both new reports and the "lumping" of allelic disorders. We report here the clinical findings and linkage studies of another new syndromic form of XLMR.

Bandeirante de Sao

Paulo (UNIBAN), Sao

Paulo, Brazil

J F Arena

University Hospital of Tromso, Norway

H A Lubs

Correspondence to:

Dr Lubs,

hlubs@peds.med.miami.edu

Revised version received 10 April 2000

Accepted for publication

1 May 2000

\section{Subjects and methods}

FAMILY REPORT

The pedigree (family K8135), with transmission of MR from five normal or minimally affected female carriers to seven affected males in three generations and the absence of male to male transmission, is consistent with $\mathrm{X}$ linked inheritance (fig 1). We examined five affected males and included information from the clinical records of a sixth affected member of the same family. No information is given on the
LINKAGE ANALYSIS

Two point linkage analysis was done with 37 polymorphic markers spread along the entire $\mathrm{X}$ chromosome using the Fastlink 3.0 program. ${ }^{7}$ The gene frequency was set at 0.0001 . Penetrance in males was set at 1.0.

\section{Results}

Patient III. 1 was the most severely affected (fig 2). There was low birth weight (1900 g), recurrent apnoea, and incubator care for two weeks and these perinatal complications may have resulted in his more severe course. All developmental milestones were delayed. At the age of 18 months, he was admitted to hospital with pneumonia, convulsions, and otitis media. $\mathrm{He}$ has required anticonvulsant therapy since. His communication was primarily non-verbal but he was able to vocalise sounds. He seemed to understand commands. Examination at 38 years (fig 2) showed an alert, non-distressed, $\mathrm{cm}(<3$ rd centile) but head circumference and eye measurements were normal. Head and neck examination showed normal hair implantation and a blind right eye (phthisis bulbi). The left eye was normal with a light reactive pupil that followed and tracked light. A prominent lower lip was present. Moderate cervicoand wheelchair bound person. Height was 157 
thoracic kyphosis was present. Cardiothoracic examination was normal. There was moderate truncal obesity. Genitourinary examination showed a normal penis and small testes $(<10$ th centile). All joints were hyperextensible and there was muscle wasting of the legs, small feet, and a calcaneal valgus deformity. Reflexes, muscle tone, and sensation were within the normal range.

Patient III. 2 was the least affected of the five males who were examined. No neonatal or childhood records were available except for a report of a functional systolic heart murmur detected at the age of 9 years. When examined at 40 years he was ambulatory and highly social, understood commands, and communicated verbally with good sentence structure. Height was $161 \mathrm{~cm}$ (<3rd centile). Weight, head circumference, canthal, and ear measurements were within normal values. There was baldness and some dental crowding, but his facial features were normal and a prominent lower lip was not present (fig 2). There was cervicothoracic kyphosis. Cardiothoracic and abdominal examination were normal except for mild truncal obesity. The penis was of normal length and testicular volume was $10 \mathrm{ml}(<10$ th centile). Distal joints were hyperextensible.
Hand measurements were normal and his feet were very small (size 5-6). Neurological examination showed mildly increased reflexes in all muscle groups and normal tone; there was muscle wasting of the legs. A fine tremor and decreased fine motor coordination in the upper limbs were present.

Patients II.3 (56 years old), III.4 (16 years old), III.5 (19 years old), and III.9 (21 years old) have most features in common with the above cases (table 1) except for the variation in severity of their mental retardation. Only III.1 had birth and neonatal complications. Tests for pituitary and endocrine function in III.9 were within normal limits and gave no evidence for panhypopituitarism or isolated growth hormone deficiency: FSH $(6.0 \mathrm{mIU} / \mathrm{ml}), \mathrm{LH}(5.0$ $\mathrm{mIU} / \mathrm{ml})$, ACTH $(26 \mathrm{pg} / \mathrm{ml})$, IGF-1/ somatomedin C (338 ng/ml), cortisol (7.6 $\mu \mathrm{g} / \mathrm{dl}$, serum), free thyroxine $(0.8 \mathrm{ng} / \mathrm{dl}$, serum), thyroxine (T4) $(4.9 \mu \mathrm{g} / \mathrm{dl}$, serum). It was not feasible to carry out a provocative test for growth hormone.

Patient III.8 was the only carrier who was examined. Her medical history included normal weight, length, and head circumference. Developmental milestones were normal. She had been evaluated for Tourette syndrome and
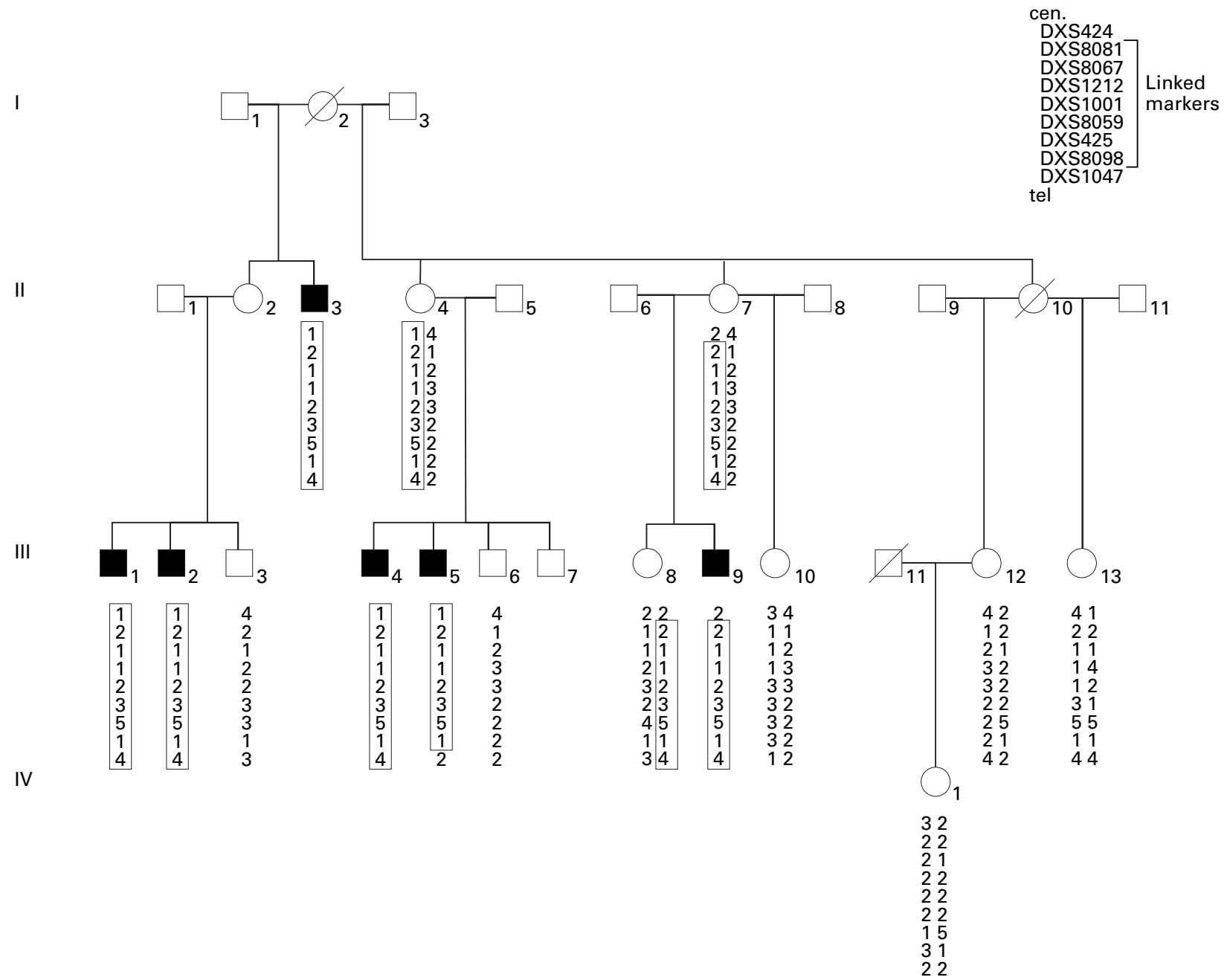

DXS8081

DXS8081

DXS1212 Linked

DXS1001 markers

DXS8059

DXS1047

Figure 1 Partial pedigree of family K8135 showing haplotypes of microsatellite markers showing six affected males. A seventh affected male and sibs were omitted since blood samples could not be obtained. Boxes indicate haplotype inherited with disease phenotype. 

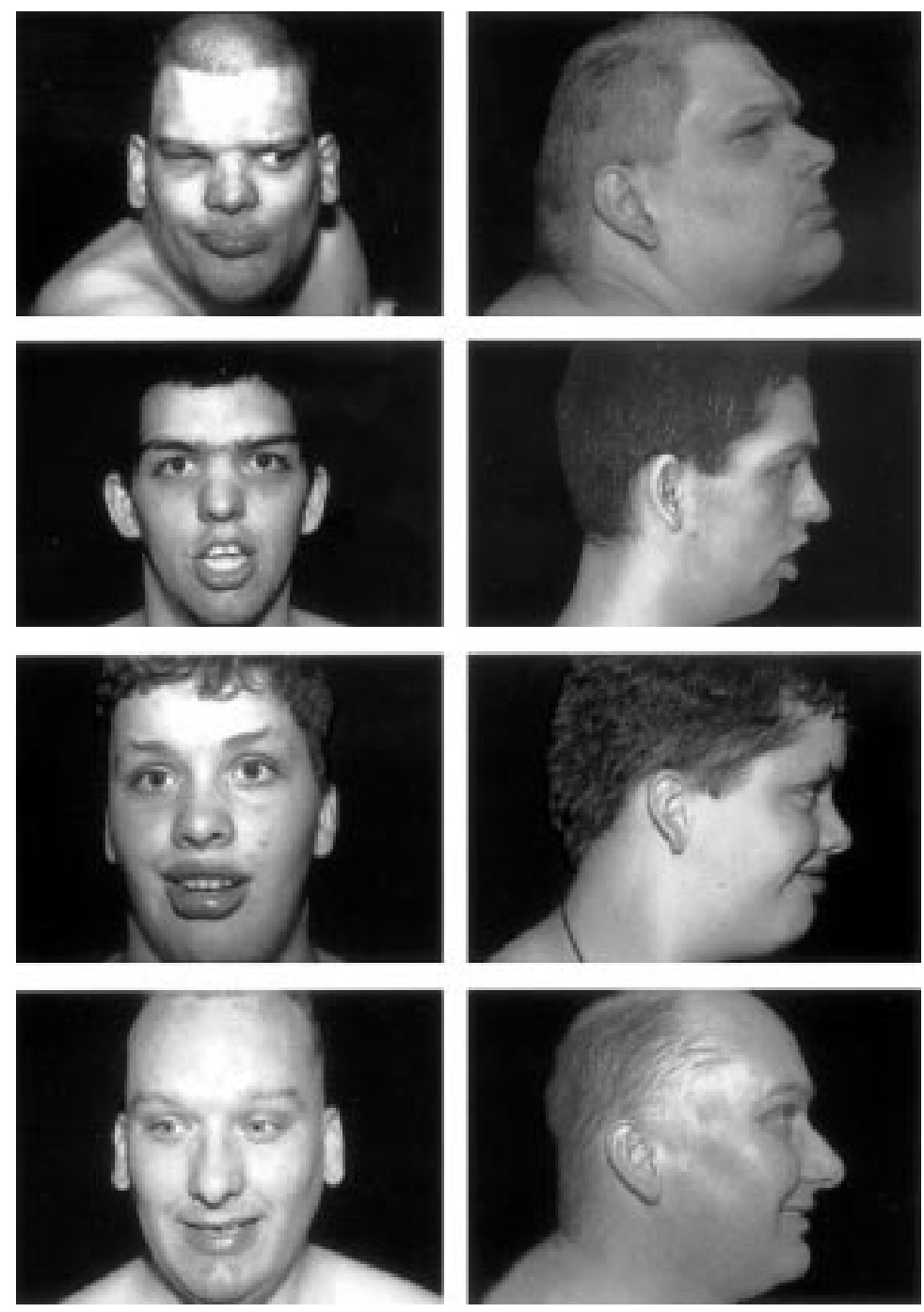

Figure 2 Facies of III.1, III.9, III.5, and III.2 (from top to bottom). Note prominent lower lips in all.

attention deficit disorder (ADD). It was reported that she had several tics (blinking, squinting, lip curling, shoulder shrugging), each present at different times, memory problems, and learning difficulties. Examination at 12 years showed only a thin habitus and mild tremor in her upper extremities.
Table 1 Clinical findings

\begin{tabular}{ll}
\hline Clinical findings & Totals \\
\hline Low IQ (range 29-54)^ & $3 / 3$ \\
Normal head circumference and eye measurements & $5 / 5$ \\
Short stature (<10th centile) & $5 / 5$ \\
Truncal obesity & $4 / 5$ \\
Prominent lower lip & $4 / 5$ \\
High palate & $3 / 5$ \\
Testes (<10th centile) & $4 / 5$ \\
Small feet (adult shoe sizes 6-7) & $5 / 5$ \\
Gap between 1 \& toes & $3 / 5$ \\
Hyperextensible joints & $5 / 5$ \\
Kyphosis & $4 / 5$ \\
Fine tremor & $4 / 6$ \\
Muscle wasting lower leg & $5 / 5$ \\
Wide based gait $\dagger$ & $3 / 3$ \\
Decreased fine motor coordination & $5 / 5$ \\
Impaired or absent speech & $4 / 5$ \\
Decreased attention span & $5 / 5$ \\
Hyperactivity & $5 / 5$ \\
Mood swings & $5 / 5$ \\
Aggressive behaviour & $3 / 5$ \\
\hline
\end{tabular}

${ }^{\star}$ IQ data obtained from available clinical reports for three affected males: five affected males were retarded by clinical examination and history.

†Two were wheelchair bound and could not be evaluated.

\section{CLINICAL COMMENTARY}

The primary clinical findings are summarised in table 1 . The ages of the affected males ranged from 16 to 50 years. Except for a prominent lower lip, the facies were normal and both stature and head circumference were normal at birth. The significant delay in growth and short stature found in five males was not documented until the prepubertal period. Testicular size was below the 3rd centile in the four affected adults who were examined. Although the testicular size in III.4 (aged 16) was not abnormal, the testicular volume $(10 \mathrm{ml})$ was identical to the older affected males. If no further increase in testicular size occurs, then his testes will also be below the 3rd centile. The shoe sizes of affected adults varied between sizes 5 and 6 . The gap between the first and second toes was striking in three of five affected males (two are shown in fig 3). Speech varied significantly in affected males. It was completely absent in one (III.1) and two (III.5 and III.9) had a vocabulary limited to only a few words. Only one (III.2) was able to communicate fairly well. Generally the affected males were passive but were easily frustrated and became aggressive when they were not able to communicate or did not receive enough atten-
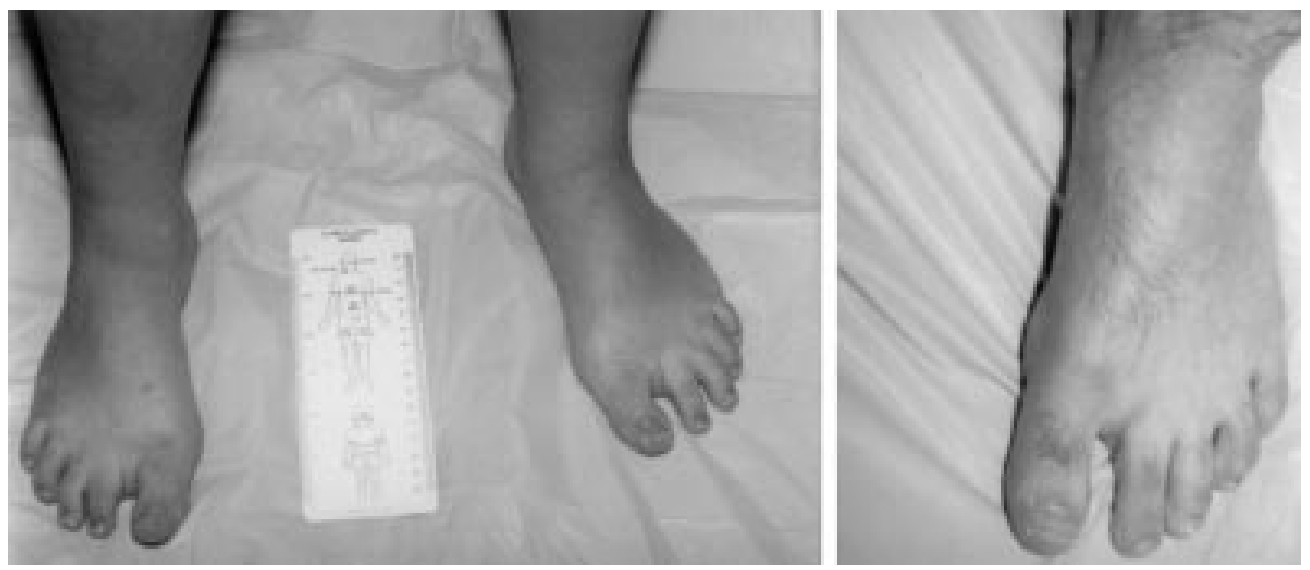

Figure 3 Gap between first and second toes in III.5 and III.9. 
Table 2 Family K8135: pairwise lod scores

\begin{tabular}{|c|c|c|c|c|c|c|c|c|c|}
\hline \multirow[b]{2}{*}{ Locus } & \multirow[b]{2}{*}{ Location } & \multicolumn{6}{|c|}{ Recombination $(\theta)$} & \multirow[b]{2}{*}{$\theta \max$} & \multirow[b]{2}{*}{$Z \max$} \\
\hline & & 0.001 & 0.01 & 0.05 & 0.1 & 0.2 & 0.3 & & \\
\hline DXS996 & $\mathrm{Xp} 22.32$ & -6.38 & -3.42 & -1.47 & -0.75 & -0.22 & -0.06 & 0.47 & 0.00 \\
\hline KAL 5' & $\mathrm{Xp} 22.32$ & -4.94 & -2.96 & -1.62 & -1.08 & -0.59 & -0.33 & 0.50 & 0.00 \\
\hline DXS987 & $\mathrm{Xp} 22.31$ & -3.89 & -3.83 & -2.64 & -1.81 & -1.01 & -0.56 & 0.50 & 0.00 \\
\hline DXS41 & $\mathrm{Xp} 22.13$ & -7.15 & -4.20 & -2.16 & -1.33 & -0.58 & -0.23 & 0.50 & 0.00 \\
\hline DXS989 & $\mathrm{Xp} 22.13$ & -7.78 & -4.95 & -2.32 & -1.26 & -0.37 & -0.01 & 0.40 & 0.09 \\
\hline DXS28 & Xp21.3 & -5.03 & -3.05 & -1.65 & -1.04 & -0.47 & -0.19 & 0.50 & 0.00 \\
\hline DXS84 & $\mathrm{Xp} 21.1$ & -1.70 & -0.72 & -0.10 & 0.10 & 0.20 & 0.16 & 0.21 & 0.20 \\
\hline DXS993 & Xp11.4 & -2.77 & -1.78 & -1.06 & -0.74 & -0.43 & -0.26 & 0.50 & 0.00 \\
\hline DXS7 & $\mathrm{Xp} 11.4$ & 0.04 & 0.04 & 0.04 & 0.03 & 0.02 & 0.01 & 0.00 & 0.04 \\
\hline DXS 255 & $\mathrm{Xp} 11.23$ & -0.71 & 0.25 & 0.81 & 0.93 & 0.85 & 0.63 & 0.12 & 0.91 \\
\hline DXS991 & $\mathrm{Xp} 11.21$ & -7.09 & -4.12 & -2.10 & -1.29 & -0.60 & -0.29 & 0.50 & 0.00 \\
\hline DXS1 & $\mathrm{Xq} 11.2$ & 0.43 & 0.41 & 0.36 & 0.30 & 0.17 & 0.06 & 0.00 & 0.43 \\
\hline $\mathrm{AR}$ & $\mathrm{Xq} 12$ & -10.66 & -6.94 & -3.62 & -2.26 & -1.04 & -0.46 & 0.50 & 0.00 \\
\hline DXS159 & $\mathrm{Xq} 12$ & 0.66 & 0.65 & 0.61 & 0.55 & 0.41 & 0.24 & 0.00 & 0.66 \\
\hline DXS1111 & $\mathrm{Xq} 12$ & -7.00 & -4.03 & -2.03 & -1.25 & -0.58 & -0.28 & 0.50 & 0.00 \\
\hline DXS106 & Xq12 & 0.68 & 0.67 & 0.61 & 0.54 & 0.40 & 0.27 & 0.00 & 0.68 \\
\hline DXS566 & $\mathrm{Xq} 13.3$ & -9.34 & -5.41 & -2.70 & -1.62 & -0.67 & -0.25 & 0.50 & 0.00 \\
\hline TCD & $\mathrm{Xq} 21.2$ & 0.80 & 0.79 & 0.72 & 0.63 & 0.46 & 0.30 & 0.00 & 0.81 \\
\hline DXS995 & Xq21.1 & -7.46 & -4.48 & -2.41 & -1.55 & -0.75 & -0.35 & 0.50 & 0.00 \\
\hline DXS326 & $\mathrm{Xq} 21.2$ & -3.65 & -1.69 & -0.43 & 0.00 & 0.25 & 0.25 & 0.24 & 0.27 \\
\hline DXS1002 & Xq21.31 & -9.34 & -5.40 & -2.67 & -1.56 & -0.59 & -0.16 & 0.44 & 0.02 \\
\hline DXYSIX & $\mathrm{Xq} 21.31$ & 0.74 & 0.73 & 0.67 & 0.59 & 0.44 & 0.29 & 0.00 & 0.74 \\
\hline DXS101 & Xq22.1 & -4.78 & -2.96 & -1.07 & -0.35 & 0.14 & 0.24 & 0.29 & 0.24 \\
\hline DXS1120 & $\mathrm{Xq} 22.3$ & -0.76 & 0.20 & 0.76 & 0.88 & 0.59 & 0.12 & 0.12 & 0.88 \\
\hline DXS424 & $\mathrm{Xq} 23$ & 0.31 & 1.26 & 1.77 & 1.81 & 1.57 & 1.16 & 0.09 & 1.82 \\
\hline DXS8081 & $\mathrm{Xq} 23$ & 1.53 & 1.51 & 1.41 & 1.29 & 1.01 & 0.69 & 0.00 & 1.53 \\
\hline DXS8067 & $\mathrm{Xq} 24$ & 1.58 & 1.56 & 1.47 & 1.34 & 1.05 & 0.73 & 0.00 & 1.58 \\
\hline DXS1212 & $\mathrm{Xq} 24$ & 2.80 & 2.76 & 2.56 & 2.32 & 1.79 & 1.23 & 0.00 & 2.80 \\
\hline DXS1001 & $\mathrm{Xq} 24$ & 1.64 & 1.63 & 1.54 & 1.41 & 1.10 & 0.75 & 0.00 & 1.65 \\
\hline DXS8059 & $\mathrm{Xq} 25$ & 1.69 & 1.67 & 1.56 & 1.42 & 1.11 & 0.77 & 0.00 & 1.69 \\
\hline DXS425 & $\mathrm{Xq} 25$ & 2.75 & 2.71 & 2.52 & 2.27 & 1.75 & 1.19 & 0.00 & 2.76 \\
\hline DXS8098 & $\mathrm{Xq} 25$ & 1.54 & 1.52 & 1.42 & 1.29 & 1.02 & 0.71 & 0.00 & 1.54 \\
\hline DXS1047 & Xq25 & -0.29 & 0.67 & 1.19 & 1.28 & 1.12 & 0.80 & 0.10 & 1.27 \\
\hline HPRT & Xq26.1 & -0.52 & 0.44 & 0.98 & 1.08 & 0.96 & 0.70 & 0.11 & 1.08 \\
\hline DXS984 & Xq27.1 & 0.13 & 0.13 & 0.13 & 0.12 & 0.08 & 0.04 & 0.25 & 0.13 \\
\hline DXS1113 & $\mathrm{Xq} 28$ & -8.57 & -6.55 & -3.96 & -2.55 & -1.21 & -0.54 & 0.50 & 0.00 \\
\hline DXS52 & $\mathrm{Xq} 28$ & -6.93 & -3.95 & -1.90 & -1.08 & -0.39 & -0.14 & 0.74 & 0.24 \\
\hline
\end{tabular}

tion. The tremor, present in five people, was present at all times and intensified during fine motor tasks. Endocrine studies in III.9 showed normal pituitary and other endocrine functions. Similarly, there was no evidence of isolated growth hormone deficiency in view of the normal IGF-1 in III.9.
LINKAGE RESULTS

Linkage analysis of 37 markers (table 2) resulted in a maximum lod score of 2.80 at DXS1212 and 2.76 at DXS425 with no recombination. The limiting markers were DXS424 (proximal) and DXS1047 (distal).

\section{Discussion}

Consistent clinical findings in the affected males included short stature, obesity (fig 4), prominent lower lip, small testes and feet, hyperextensible joints, and kyphosis. In three of five subjects, a gap between the first and second toes was also found. Consistent neurological findings included fine tremor of the upper limbs, decreased fine motor coordination, significant muscle wasting of the lower legs in five subjects, and a wide based gait in three. Two were wheelchair bound. Decreased attention span, hyperactivity, and mood swings were present in 5/5 affected males. Aggressive behaviour was also present in $3 / 5$ subjects. These clinical findings have not been previously reported in a family with XLMR. ${ }^{2}$

The linkage results place the gene in Xq24Xq25. As shown in fig 5, eight MRX families and 10 syndromes have localisations which overlap with the present family. The clinical differences make it unlikely these disorders are allelic, but allelism is possible for either the MRX or syndromic disorders since there has recently been a report of an MRX family resulting from a mutation in a known syndrome. ${ }^{8}$

The family reported by Turner et al with mild Borjeson-Forssman-Lehmann syndrome (BFL) overlaps partially with the present localisation, that is, between DXS10 and DXS8098. In this family the majority of affected males had short stature, obesity, small testes, and a gap between the first and second toes. However, many

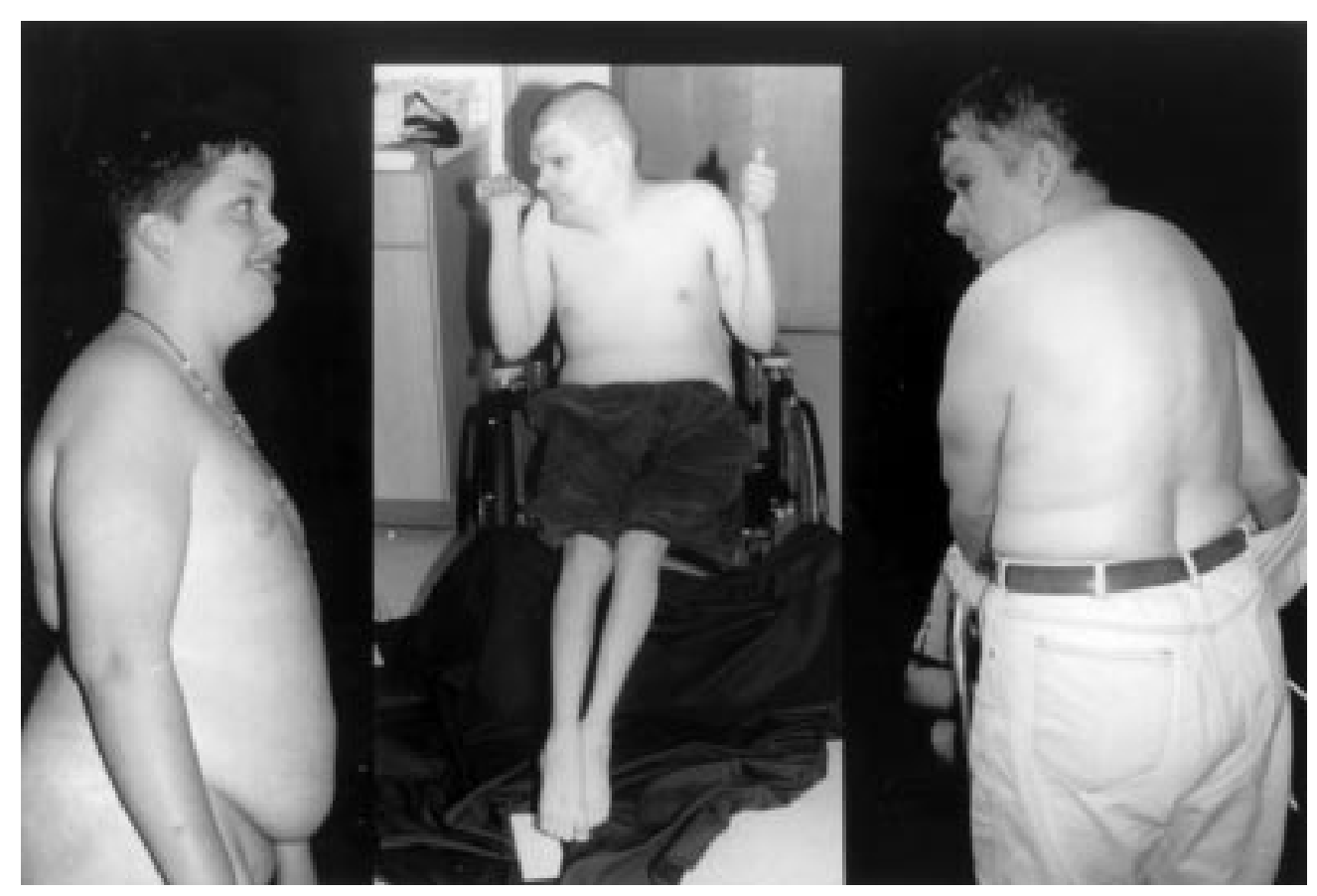

Figure 4 Obese habitus in III.5, III.1, and II.3 ( $L$ to $R$ ). 


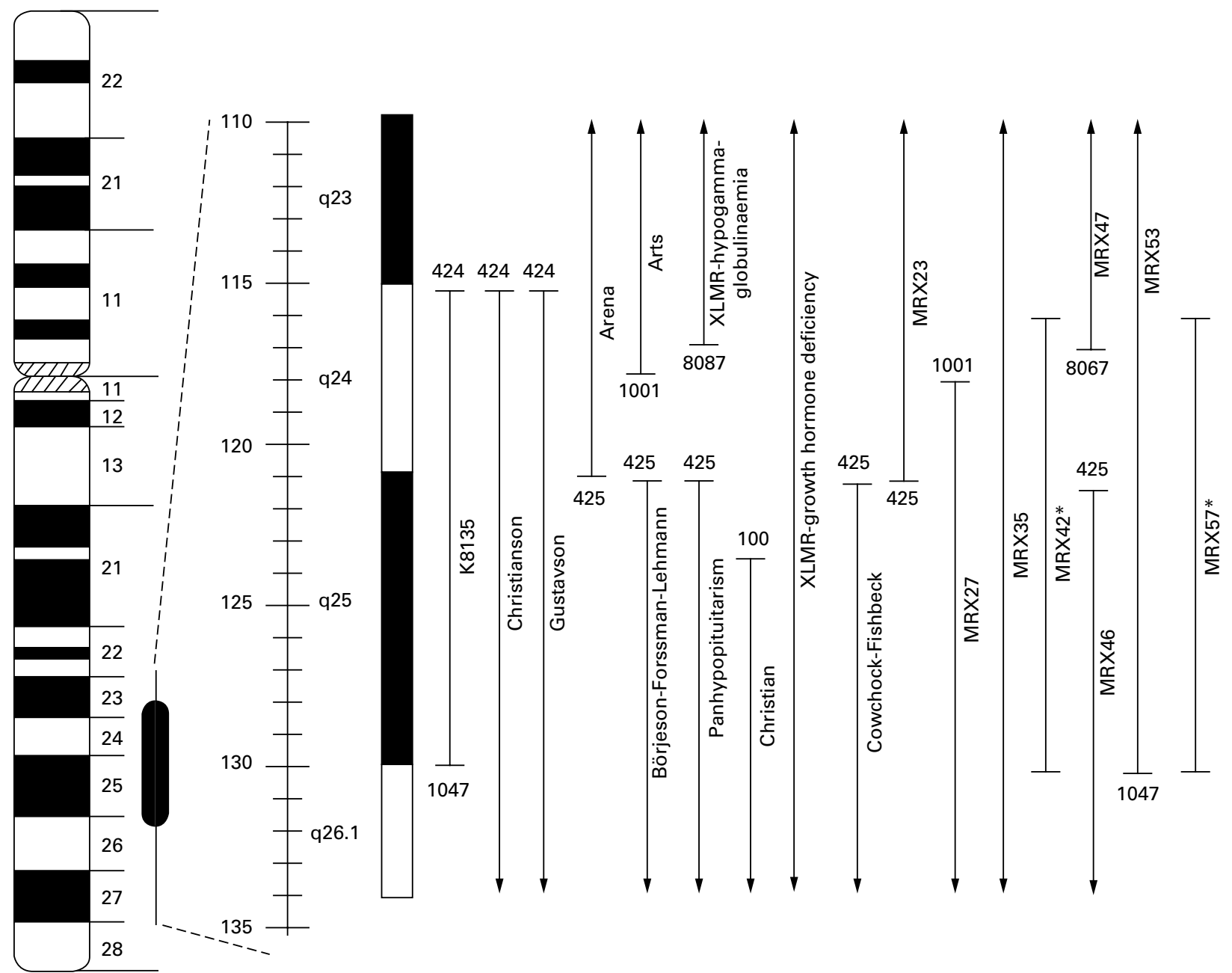

Figure 5 Schematic of Xq24-Xq27.3 showing linkage limits for family K8135 and other XLMR entities that map to the region. DXS probe numbers are given at the limits of localisations.

significant differences were also present. No one in the present family had large ears or a small penis, and the BFL family had a different facies with no prominent lower lip or high palate. In addition, no one had small feet. The small toes in BFL were different and the muscle wasting and neurological findings shown in table 1 were not present. Although BFL and the present disorder might be allelic, on a clinical basis they appear different.

Thirty six of the known XLMR syndromes include short stature and hypogonadism occurs in 18. Panhypopituitarism (PHP) $(\text { MIM 312000) })^{10}$ and isolated growth hormone disorder (IGHD) (MIM 300123) ${ }^{11}$ localise to the same region (fig 5). Both have short stature but neither syndrome includes small testes. Tests of pituitary and endocrine function in the present family also did not support either of these diagnosis. The tremor in the present family, which was a constant, fine tremor, differs from the Parkinsonian tremor seen in Waisman-Laxova syndrome (MIM 311510) and in the intention tremors described in the Pettigrew syndrome (MIM 304340) and ataxia dementia (MIM 301840).

The remaining XLMR syndromes (Christianson et al, ${ }^{12}$ Gustavson (MIM 309555),
Arena et $a l,{ }^{13}$ Arts (MIM 301835), Christian (MIM 309620), Chudley et $a l,{ }^{14}$ and Cowchock-Fishbeck (MIM 310200), which overlap the present localisation, do not have significant clinical similarities. Only molecular studies following the cloning of these several disorders will resolve the issue of possible allelism for this group of XLMR disorders. None of these disorders, however, has currently been cloned.

This study was funded in part by a National Institutes of Health grant (RO1 HD26202) to the University of Miami, School of Medicine (HAL) and the Greenwood Genetics Center (CES). The ethical and human aspects of these studies have been approved by Human Subjects Committees at each of the approved by Human Subjo
collaborating institutions.

1 Lubs HA, Chiurazzi P, Arena JF, Schwartz CE, Tranebjaerg L, Neri G. XLMR genes: update 1996. Am $F$ Med Genet 1996;64:147-58.

2 Lubs H, Chiurazzi P, Arena J, Schwartz C, Tranebjaerg L, Neri G. XLMR genes: update 1998. Am f Med Genet 1999; 83:237-47.

3 Schwartz CE, Ulmer J, Brown A, Panscot I, Goodman HO, Stevenson, RE. Allan-Herndon syndrome II. Linkage to DNA markers in Xq21. Am f Hum Genet 1990;47: 454-8.

4 Nelson DL, Ballabio A, Cremers F, Monaco AP, Schlessinger D. Report of the Sixth International Workshop on chromosome mapping 1995. Cytogenetic Cell Genet 1995; 71:308-36.

5 Dib C, Faure S, Fizames C, Samson D, Drouot N, Vignal A, Millasseau P, Marc S, Hazan J, Sebourn E, Lathrop M, Millasseau P, Marc S, Hazan J, Sebourn E, Lathrop M, Gyapay G, Morisette J, Weissenbach J. A comprehensive genetic map of the human genome based on 5,264 micros-
atellites. Nature 1996;380:152-7. 
6 Mansfield DC, Brown AF, Green DK, Carothers AD, Morris SW, Evans HJ, Wright AF. Automation of genetic linkage analysis using fluor

7 Cottingham RW Jr, Idury RM, Schaffer AA. Faster sequential genetic linkage computations. Am f Med Genet 1993;53:252-63.

8 Merienne K, Jacquot S, Pannetier S, Zeniou M, Bankier A Gecz J, Mandel JL, Mulley J, Sassone-Corsi P, Hanauer A. A missense mutation in RPS6KA3 (RSK2) responsible for non-specific mental retardation. Nat Genet 1999;22:1314.

9 Turner G, Gedeon A, Mulley J, Sutherland G, Rae J, Power $\mathrm{K}$, Arthur I. Borjeson-Forssman-Lehmann syndrome: clinical manifestations and gene localization to Xq26-27. Am ₹ Med Genet 1989;34:463-9.

10 Raynaud M, Ronce N, Ayrault AD, Francannet C, Malpuech G, Moraine C. X-linked mental retardation with Xq27.2 in one family. Am f Med Genet 1998;76:255-61.
11 Hamel B, Smits A, Otten BJ, van den Helm B, Ropers HH, Mariman E. Familial X-linked mental retardation and iso(n) clinical and molecular findings. Am $\mathcal{F}$ Med Genet 1996;64:35-41.

2 Christianson $\mathrm{AL}$, Stevenson $\mathrm{RE}$, van der Mayden $\mathrm{CH}$, Pelser J, Theron FW, van Rensburg PL, Chandler M, Schwartz CE. X-linked severe mental retardation, craniofacial dysmorphology, epilepsy, ophthalmoplegia, and cerebellar atrophy in a large South African kindred is localised to Xq24-q27. F Med Genet 1999;36:759-66.

13 Arena JF, Schwartz C, Stevenson R, Lawrence L, Carpenter A, Duara R, Ledbetter D, Huang T, Lehner T, Ott J, Lubs HA. Spastic paraplegia with iron deposits in the basal ganglia: a new X-linked mental retardation syndrome. Am $\mathcal{7}$ Med Genet 1992;43:479-90.

14 Chudley AE, Tackels DC, Lubs HA, Arena JF, Stoeber WP, Kovnats S, Stevenson RE, Schwartz CE. X-linked mental retardation syndrome with seizures, hypogammaglobulinemia, and progressive gait disturbance is regionally mapped between Xq21.33 and Xq23. Am ₹ Med Genet 1999;85:255-62. 